\title{
Ethnologies
}

\section{The Convict and the Colonel. A Story of Colonialism and Resistance in the Caribbean. By Richard Price. (Durham: Duke University Press, 2006. Pp 296 With a new afterword.; Originally pulblished by Beacon Press, 1998. ISBN 0-8223-3823-8)}

\section{Joseph Stahlman}

Volume 32, numéro 1, 2010

Jouer

Play

URI : https://id.erudit.org/iderudit/045223ar

DOI : https://doi.org/10.7202/045223ar

Aller au sommaire du numéro

Éditeur(s)

Association Canadienne d'Ethnologie et de Folklore

ISSN

1481-5974 (imprimé)

1708-0401 (numérique)

Découvrir la revue

Citer ce compte rendu

Stahlman, J. (2010). Compte rendu de [The Convict and the Colonel. A Story of Colonialism and Resistance in the Caribbean. By Richard Price. (Durham: Duke University Press, 2006. Pp 296 With a new afterword.; Originally published by Beacon Press, 1998. ISBN 0-8223-3823-8)]. Ethnologies, 32(1), 226-229.

https://doi.org/10.7202/045223ar d'utilisation que vous pouvez consulter en ligne. 
The Convict and the Colonel. A Story of Colonialism and Resistance in the Carlbbean. By Richard Price. (Durham: Duke University Press, 2006. Pp 296 With a new afterword.; Originally published by Beacon Press, 1998. ISBN 0-8223-3823-8)

Let me start off by stating that Richard Price's The Convict and the Colonel is a complicated book. Not in the sense that it was difficult read, but I spent the first 38 pages wondering where he was going to take his readers. By the time I got to the second chapter I realized where he wanted to take his readers. Still, I could not figure out if this effort was a book on history, on postcolonialism, or a biography. In hindsight, the book has all those ingredients plus anthropology, folklore, entwined in a discussion of collective memory. After I settled into Price's writing style I began to appreciate his exercise much more. Throughout the book Price makes use of oral and documented histories, postmodern and traditional narratives, and personal and collective memories to provide a larger view of Martinique of the last century. Price's book is an incomplete history of Martinique from the 1925 Massacre of the Diamant to the story of the convict and eccentric folk artist, Médard to the immediate present. It is Médard's 'photo', actually a bust, of the colonel is the important element that ties the book together.

The book is divided into three sections, each focusing on three historical moments. The first section reconstructs the events of the 1925 election. For Price the election serves as a precipice between the apex of colonial rule and the beginnings of Martiniquan modernity. This section is divided into two columns that made reading this chapter arduous; on the right, the French official account, and on the left, later local and leftist's recounting. The division of the left and right columns is also categorizing the various elements during this explosive time, when in all probability there were additional positions and philosophies not being considered by Price. This categorization left me feeling that Price's positionality on Martinique a little too dualistic. At first it was difficult to simultaneously read the two columns and it never became any easier. This device, as novel as it seems, is one that relegates readers to subconsciously take and not really decide for themselves about this historic moment.

Sometimes the stories of resistance are best understood from an individual perspective. I feel that Price understood this and he does it effectively in his second section. He presents the story of Médard and is able to show through example how oral and official histories do not 
necessarily contradict each other, but instead lend a bigger view into the story wanting to be told. In the local stories of Médard, people say that he was arrested for his 'photograph' of the colonel; however, according to Price's research in colonial records, Médard was incarcerated for common thievery. What these two versions do is contribute to Price's efforts to demonstrate how Médard resisted colonial authority and maintained level of autonomy that is often missed in postmodern subaltern literature.

Médard's importance outside of this construction should be questioned. First, Price never knew him. Médard wasn't in Price's radar in the first twenty years on the island. Second, For Médard's contemporaries and for Price, it seems that Médard's importance came postmortem. The role Médard plays is more important to our present more so than in his own life. As a result of this late influence, Médard has become part of Martiniquan life. It appears that the locals, the Creole elite, and France have usurped Médard's folk art and his little house to make it part of the post card tourist culture of Martinique.

Part III moves readers to the present where the memory of Médard serves as a critique of the colonial hegemony over the Martiniquans. Through Price's efforts readers observe how France continues to appropriate memories in order to correct past transgressions, but to also whitewash some of the more devastating acts of colonialism. The effect is that it becomes what Price calls the "folklorization of the colonialism" (173). This device becomes dangerous to those who continue to be subjected by the Colonial or Postcolonial efforts. People develop amnesia. We can observe how these memories in North America with the folklorization of civil rights struggles and youth culture movements from the 1960s and 1970s. The memories become coopted by the State and the bourgeois and no longer represent the subalterns. Price also fixes on bringing the past to the present, and embedding realities in fictions. He attempts to deal with questions, but he is also asking the discipline what do we do with them? In the end authenticity remains the most elusive item. History, or chunks of it, is desired by many, especially those in power.

Price's intention with this book is obvious. On page 157, he states "[m]y aim here is to explore how one generation's powerful historical metaphors could so quickly become the next generations trivial pursuit...I will try to shed light on how a people's central mnemonic for 
colonial repression could fit itself transformed, in less than two decades into anodyne and picturesque icon on the cover of France's best-selling tourist of Martinique" (157). Price seems to have focused on Médard because of his beautiful folk art, his queer proclivities to live in caves, and his long-term unnecessary imprisonment for his personal autonomy. As we gain insight into Médard, we also earn wisdom into the complexities of creolization in Martinique. Subsequently, many, including the bourgeoisie and the State, have coopted the Convict in order to promote tourism or ethnic pride. Price is well aware of how this has been subject to the present. Present Creole elites employ Médard on many levels while as Price presents Médard as a resister to colonial denomination.

The Convict and the Colonel focuses on the often discussed discourses of Caribbean colonial settings, such as Martinique which remains under the authority of France. The elements of these discourses include the continuum of color associated with privilege and rights, and the 'madness' linked to the displacement of modern African and European identities. As stated earlier, Price places these identities as dialectics, but should be viewed as continuums that properly arrange actors within an array of possibilities. Nonetheless, he regresses back to what Dubois called "double-consciousness", the ability for the repressed to fashion a future from the master's tools, and at times, the master's versions of history. For Price, and DuBois and Herskovits, it is up to the subalterns to carve out identities and solutions within their respective settings, and it offers a plausible explanation for Médard's unusual 'madness'.

Additionally, it is Price who has also romanticized the island and his discovery of his own paradise. I feel that Price longs for the days of being with old friends, falling in love, fishing, and believing in magic. His true contribution is his ability to conjure a good story that informs our field on the limitations and transformations of memory and of the places we become part. It could be that Médard's madness is also Price's madness for wanting to return to his idyllic 1962.

I feel late reading this book. I should have read it ten years ago. I enjoyed the book on many levels. Price delves into history, memory, landscape, ethnographer's dilemma with self, and one's desire to return to an idyllic past. Mostly, I feel that Part I is essential because Price shows the ways we remember: poetry, oral histories, government documents, letters, memoirs, artifacts, and old field notes. ; His columns, 
however, should be seriously reconsidered. Lastly, I think two of the finer points of this book are Price's ability to weave all of these strands together and to expose a little of himself so we can better understand the complexities of memory. By Price researching this chunk of Martinique history, he also stumbles onto a piece of French history in the Caribbean that is often missed.

Joseph Stahlman Indiana University

Bounty Chords. Music, Dance and Cultural Heritage on Norfolk and Pltcalrn Is/ands. By Philip Hayward. (London: John Libby Publishing, 2006. Pp. viii +248, ISBN 0-86196-678-3.)

In this text's introduction, Hayward states that "While heritage and tradition are often invoked as something fixed and essential, they are conversely - fluid and contentious, subject to various changes and interpretations, disputes and affirmations." In the cultural heritage and history of Norfolk and Pitcairn Islands, such a statement rings quite true; the two colonies, both originally British dependencies (Norfolk Island is now a colony of New Zealand), have a history in which one island culture has made a significant impact on the other.

A mix of history, ethnomusicology and culture studies, Hayward's book provides a chronological examination of the role of music in the identity of Norfolk and Pitcairn Island communities. Hayward states that "In particular, I offer analyses of the manner in which the culture of Norfolk and Pitcairn Island have been created and re-created through processes of adoption and synthesis." Such synthesis is evident in the smooth transition between Hayward's examination of these island cultures connected by a single event: the Bounty mutiny. The famous mutiny, however, is only the beginning of Hayward's text.

Apart from establishing a discussion of the expressive culture of Norfolk and Pitcairn Islands, Hayward also tells of how both islands were settled. While discussing the islands' settlement, he does an excellent job of intertwining the role of music and dance in a society compounded by British Protestants and Polynesians. Letters, journals, and personal experience narratives of early settlers are put to good use in describing the emotions of settlement, and song lyrics also provide an example of the ideals held by the colonists. Such lyrics sometimes stand in sharp 